\title{
24
}

PROJECT MUSE

\section{Fighting Words in the Antipodes}

Cherie Lacey, Michael P. Kelly, Annemarie Jutel

Perspectives in Biology and Medicine, Volume 63, Number 4, Autumn 2020, pp. 669-682 (Article)

Published by Johns Hopkins University Press

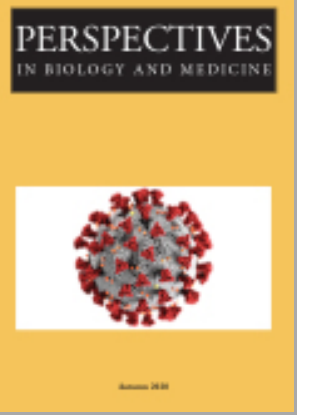

$\Rightarrow$ For additional information about this article

https://muse.jhu.edu/article/775635 


\section{FIGHTING WORDS IN THE ANTIPODES}

Cherie LACEy,* Michael P. Kelly, † ANd ANNemarie Jutel

ABSTRACT In this commentary, written in two bursts- the first completed in April 2020, and the second at the end of July - we explore how media metaphors of COVID-19 constitute the pandemic in Australia and New Zealand. We argue that the media's rhetorical strategies play an important role not only in describing the illness, but in influencing and shaping individual and collective responses to the pandemic, with significant consequences for mental health and well-being in the context of crisis. We align this commentary with the tenets of the sociology of diagnosis, which argue that even though there are material realities of disease, their social form and consequence cannot be separated from the tangible nature of illness and its management. We also lean on Derrida's approach to metaphor, which underlines how even observable viral entities such as COVID-19 are simultaneously material, abstract, and in flux. We describe the metaphors used by local media to describe the pandemic-including combat, bush fires, earthquakes, and other natural disasters - and we explore how and why these metaphors construct the pandemic locally and farther afield.

\footnotetext{
*School of English, Film, Theatre, Media Studies, and Art History, Te Herenga Waka/Victoria University of Wellington, New Zealand.

†Primary Care Unit, Institute of Public Health, University of Cambridge, United Kingdom. $\ddagger$ Faculty of Health, Te Herenga Waka/Victoria University of Wellington, New Zealand.

Correspondence: Annemarie Jutel, Professor of Health, Faculty of Health, Kelburn Parade, Te Herenga Waka/Victoria University of Wellington, New Zealand.

Email: annemarie.jutel@vuw.ac.nz.
}

Perspectives in Biology and Medicine, volume 63, number 4 (autumn 2020): 669-682.

(C) 2020 by Johns Hopkins University Press 
$\mathrm{I}$ N THIS COMMENTARY, we explore how media metaphors of COVID-19 constitute the pandemic in Australia and New Zealand. We argue that the media's rhetorical strategies in coverage of COVID-19 play a role not only in describing the illness, but in influencing and shaping our individual and collective responses to the pandemic, with significant consequences for mental health and well-being in the context of crisis. We align this commentary with the tenets of the sociology of diagnosis, which maintain the social form and consequence of disease cannot be separated from the tangible nature of illness and its management (Aronowitz 2008; Jutel 2011).

Viral outbreaks are not merely biological events (Caduff 2019); they unfold as assemblages through information networks that use a range of techniques to generate emotion, even while hinged to scientific materiality (Soncul 2018). These assemblages are produced in many media and have a significant role in shaping health behaviors (Gray et al. 2005; Vaterlaus et al. 2015). However, the general tendency towards hyperbole by both media and politicians - motivated by agenda-setting, influence, and profit in an attention economy-can elicit inappropriate and unhelpful responses in the public, producing feelings of panic, fear, or powerlessness.

Looking at discussions of COVID-19 in the New Zealand and Australian press in the weeks leading up to Alert Level 4 in New Zealand, and its equivalent in Australia, the media appeared to be caught in a bind. They needed to promote compliance in the general population by echoing official messaging, but at the same time, they were in the service of an economy that rewards sensationalism: the more compelling the content, the longer the reader stays on the page, and the more the story is shared along information networks (Crawford, Hunter, and Filipovic 2015). On any one day, calls for kindness, calm, and compassion were juxtaposed with headlines about the virus being a "war against humanity" (New Zealand Herald 2020), or the virus as our generation's "bubonic plague" (Powell 2020).

What is apparent in these discussions is that, to borrow the words of Alan Bleakley (2017), COVID-19 is "soaked" in metaphor (13). In this article, we explore not only what these metaphors are, but how they constitute the pandemic according to their social context, generating culturally specific images of COVID-19, and shape the public's emotional responses.

This reliance on metaphors to communicate illness should not surprise readers familiar with the work of Susan Sontag, and her Illness as Metaphor (1978). She revealed what any literary scholar could easily recognize: physicians explain complex concepts with the use of metaphor, and most frequently (at least in reference to her example of cancer) metaphors of war and battle. Cancer is itself a metaphor, used to describe nefarious infiltration of many kinds: the cancer of corruption, or the cancer of betrayal (Potts and Semino 2019). Infectious disease is no different. Descriptions of the 2006 avian flu relied upon military invasion 
metaphors (Hanne and Hawken 2007), and the 2009 H1N1 pandemic did the same, adding an extra emphasis on national border infringement (Jutel 2013).

When we speak of metaphor, it is generally understood that we are referring to the "perception of similarities or correspondences between unlike entities and processes, so that we can see, experience, think and communicate about one thing in terms of another" (Semino and Demjén 2016, 1). A metaphor seems to ascribe a property to an object it does not actually have. This may be simultaneously illuminating and unhelpful. The very word metaphor, meaning "transport across," is itself a metaphor, as it represents a rhetorical technique in spatial terms (Wheeler 2016).

Jacques Derrida's $(1974,1982)$ work on metaphor is generally considered one of the most sophisticated engagements with the uses of metaphor in communicating meaning, and remains influential to this day. His work invites us to understand how metaphors create a world, rather than capturing, or describing, it. This overturns the commonly held notion that metaphor can reveal a thing by relating it to something else. "The ideal of all language, and in particular of metaphor," he writes (and his use of the word ideal here should immediately put us on guard), is to "allow the thing itself to be known," to bring us to "the thing's essential or proper truth" (Derrida 1974, 48). However, as Novitz (1985) emphasizes, what Derrida intended to convey is that the metaphor itself is the means for creating a particular conception of the world. The use of metaphor is not to capture a "transcendental signified," rather it is to "choose a vocabulary, and so create (rather than discover) significance-thereby inventing, rather than finding, reality" (104). In this sense, the power of metaphor comes from its ability to generate concepts and meanings, as well as to reveal them.

One idea Derrida explored is that metaphors can "manifest properties" between otherwise unrelated concepts (Derrida 1974, 13). That a metaphor can "manifest" the properties of one thing in something entirely different is intriguing; the two things must therefore share a fundamental property. The allure of metaphor is to have privileged access to this fundamental property as the "discourse of full truth." This is why metaphors are so seductive: they promise access to a higher purpose, deeper understanding, or a meaning that transcends ordinary language (Bleakley 2017). However, what Derrida teaches us is that this "sensation" provided by metaphor is an effect of language itself. Metaphor offers us a sensation of higher meaning that is quite persuasive in shaping our understanding of events.

What must be made explicit is that the shared fundamental property linked by a metaphor is figurative, or constructed by language. In relation to COVID-19, it is important to understand what properties are thus attributed to and mobilized by metaphor, as well as in what the metaphors are of service. This is because metaphor creates images of reality — a sense of truth — on which we base thought and action. 
The actions of the public are pivotal in the pandemic setting. Many viruses and bacteria, and COVID-19 in particular, are spread by social practices that have taken-for-granted qualities (Schutz, 1967, 1970; Shove, Pantzar, and Watson 2012). The vectors of infection remain hidden in ordinary habitual behaviors. Talking to people, shaking hands, coughing, touching things, using public transportation, sharing a meal, and having a beer in the pub are all potential moments of transmission. Those moments are both familiar and suddenly potentially deadly. It is hardly surprising that those seeking to alert the public to danger seize upon metaphor to underline the threat.

For example, in the modern West, war is a relatively rare direct experience for most people alive today. Mostly, we know war only through representations in film or on television, or through news footage. The images we have been exposed to by the media are, likely, what supplies the meaning and content to warlike metaphors: they create the "image of reality" that is invoked by such metaphors. Given the highly affective nature of war media (especially, it might be argued, war films), the sensations that are generated by war media become "manifested" in another place - in our case, they are transported across to COVID-19. The underlying property that is called forth by the use of warlike metaphors in describing the virus, then, does not anchor our understanding of the illness in a "full truth." Our sense of clarity about the virus is an illusion, and the truth we might feel we glimpse in the metaphor is constructed. What metaphors such as these do, however, is affect our behavior and response to the pandemic: they might, for example, work to mobilize, alert, and assign legitimacy to extraordinary actions, such as declaring a state of emergency.

We could start with the metaphor "outbreak," which readers may not have even considered as a metaphor. They would be (partly) correct. The Oxford Dictionary defines this term as "a sudden occurrence . . of disease." It is what we can call a "dead" metaphor: one which today evokes almost exclusively contagion, the thing for which it was originally a metaphor, even while the word still literally depicts the fracturing of a barrier out of which something emerges. The earliest reference to the word was related to emotion: Hamlet's "The flash and out-breake of a fierie mind" (II. i. 34)). Its usage was to shift to the emergence of hostilities in a military context, and finally to the sudden increase in the incidence of disease for which it is now a standard definition. This demonstrates the ways in which the COVID-19 outbreak might be conceptualized at the same time as a "mental contagion" (Okri 2020) and as a "Bracing for War" (Chun and Aubusson 2020). In this case, properties are transferred from one language context to the next, producing a "drift" of meaning (Derrida 1967, 69). The key idea here is that the metaphor generates the property, which then gets retroactively attributed to the pandemic as though there was some natural or "correct fit" between the two phenomena. 
What are the properties that COVID-19 metaphors generate, and how do they contribute to the experience of an event by a broader public? In short, what emotions and actions are evoked by the metaphors of COVID-19?

Combat is one, but not the only, metaphor used to describe COVID-19. The virus is, not unexpectedly, also referred to as "deadly" (Todd 2020) and a "killer" (Dyer 2020). We have been instructed to go into "lockdown" (BBC/ RNZ 2020; Harris 2020) and to "shelter in place" (Peters 2020), conferring on COVID-19 features associated with an attacking army. Health professionals are described as being "on the front line," and "in the trenches" (Brindley 2020), and many news outlets are proclaiming that we are in a "war against COVID-19" (Clun and Aubusson 2020b; Dunlevey 2020; Kelly 2020).

In Australia and New Zealand, metaphors of natural disasters are also commonly used to construct the COVID-19 pandemic. In Australia, COVID-19 is frequently linked to bushfires, with media saying that it will "spread like wildfire" (Mannix, Clun, and Aubusson 2020), "sparking” panic and fear (Ireland 2020). In New Zealand, we see the media claiming that the virus will have a "short, sharp shock" (Dann 2020b), in line with its sustained experience with major earthquakes. Water metaphors like "deluge" (Clun and Aubusson 2020a), "inundation" (Aubusson, McCauley, and Clun 2020), "waves" of infection (Clun 2020), and a "perfect storm" (Dann 2020a; Walls 2020) contribute to the image of the virus as a natural threat against which the nations are more or less powerless.

We should point out that the natural disaster narrative is not new in relation to pandemics: Caduff (2019), writing about the "pandemic prophesy," argued that the US government and the Institute of Medicine (IOM) had actively cultivated the idea that an influenza pandemic posed a catastrophic threat in order to drum up more respect for the virus. This narrative was intended to "motivate action, mobilize resources, and create more interest in preparedness, nationally and internationally" (10). The result of this narrative was a "call to change," Caduff argues, offering the public a blend of pessimism ("a pandemic is unavoidable") and optimism ("disaster could be mitigated if the right steps are taken").

Farther afield, UK media outlets have deployed war metaphors explicitly linked to WWII, imploring citizens to adopt a "Blitz spirit" to the pandemic (Hannon 2020). When the government called to close pubs, one journalist complained: "even the Blitz couldn't close our pubs. This is a bitter blow" (Pelling 2020). A favorite metaphor used by UK Ministers is of the population "being all in it together," deliberately invoking popular films that use the shared privations of civilian and military personnel as narrative glue.

In the US, metaphors derived from popular culture proliferate, linking COVID-19 to the "zombie apocalypse" (Krugman 2020) and describing scenes in cities and hospitals with reference to The Day After Tomorrow, Children of Men and other postapocalyptic, science fiction films (Lutz 2020). These differing national metaphors of COVID-19 highlight how the virus is, at least in part, socially 
and culturally constituted by the language in which it is described-simultaneously material, abstract, and in flux.

Sontag (1978) argued that the metaphors of cancer were ill suited, going so far as to suggest that medicine should seek to avoid metaphors: "illness is not a metaphor, and . . the most truthful way of regarding illness - and the healthiest way of being ill - is the one most purified of most resistant to, metaphorical thinking" (3). Sharing this perspective, many have called for the metaphors used in describing COVID-19 to be more judiciously chosen (Jutel 2020; Tisdall 2020; Weiner 2020).

But, as we see it, one bottom line is that metaphor is a way of making a judgment on the basis of an image of reality (Raffel 2013). Therefore, it's important to get metaphor right, particularly in relation to metaphors that intend to generate social action, such as complying with or reporting public health directives. How might we get to the "discourse of full truth" about COVID-19?

Of course, we might pause and underline here the uncertainties and paradoxes embedded in the diagnostic systems of public health, to punctuate just how difficult a "full truth" is, even in epidemiological terms. As critical diagnosis scholars, we must emphasize that diagnoses are fluid categories that attempt to generalize about an individual case, saying that the way a person feels can be understood by a generic term that condenses a whole array of symptoms. The diagnosis becomes the "full truth" of the ailment, legitimizing the complaint, and setting out a course of expected responses. However, in an epidemic setting, even concrete diagnoses with empirically detectable causes have complicated physical and social realities that their evolving metaphors embody (Jutel 2013). The case definition changes regularly and varies from setting to setting (ECDC 2020; Ministry of Health 2020a 2020b). Carriers may be asymptomatic, and the viral strains are in flux, making COVID-19 abstract even within its empirical parameters (Tang et al. 2020).

Daniel Kahneman (2011) has described how humans default to the use of heuristics, including metaphors, a shorthand way of thinking that avoids dealing with the true complexity of the phenomenon in question and appears to, or at least invites, simple answers to what are complex problems. Metaphors offer what Bleakley (2017) calls a "comfort blanket" (2), especially in contexts of uncertainty. The COVID-19 virus is novel, without an off-the-shelf vaccine or clinical guideline; there are no easy answers. To arrive at an understanding of prognosis and therapeutics will require a lot of what Kahneman (2011) calls slow thinking - the opposite of the fast and unthinking use of heuristics or metaphors. This will involve deep cognitive engagement with the microbiology of the virus, the behavioral and epidemiological aspects of its transmission, the clinical prognostic and therapeutic consequences, and the psychological, social, and economic complexities intrinsic to the pandemic for individuals and populations. 
While many jurisdictions and most public health authorities have had responses ready for an expected pandemic for many years, these cannot, of necessity, be detailed enough to handle all the peculiarities of this or any other particular virus. We have been lucky in the most recent past with outbreaks like swine flu and SARS, because the virus never became established and never led to a pandemic. To implement prevention strategies now requires elaborating on the extant plans by slow deliberate thinking, by engagement with the complexities mentioned above. It also requires honesty and transparency in communications with the public about the fact that there are no ready, easy, or simple answers. Shorthand heuristics from warlike or other metaphors, which seem to provide obvious answers, can be as dangerous as they are seductive.

Perhaps the greatest danger with any metaphor that encourages people to action is that, in Derridean terms, the thing with which the comparison is being made constructs the event. It becomes the reality and generates, in addition to actions, emotions that are quite possibly unsuited to a health crisis and to appropriate individual and public health actions.

Dealing with a viral pandemic is a public health emergency that requires a good understanding of social life and human psychology. It requires medical, governmental, and economic solutions. It does not require calls to arms. The virus is not an enemy with human agency acting malevolently towards us: it is carried by human beings and is transferred in human interactions and social practices. And in order to slow down the rate of infection, public health action will need to focus on those human interactions and practices. The virus won't be defeated on a battlefield, it will be analyzed in laboratories, and the resulting antidote and antigen and antibody tests will be administered in clinical trials. This isn't war, it's medicine. Less dramatic perhaps, but true nonetheless.

\section{POSTSCRIPT}

Since we took our initial snapshot, there has been a marked shift in the metaphors used in New Zealand to talk about COVID-19. Beginning on March 21, 2020, New Zealand has used an alert level system as a major component of containment of the virus. On March 26, the country was put into Level 4, or lockdown, with only essential businesses (food and medicine) allowed to operate, and all people confined to their homes. By April 27, the country had moved to Level 3, with minor expansion of activities. Businesses could operate in a contactless manner (delivery or pick up), with people allowed to exercise further from their homes. Level 2 was a controlled return to business with social distancing, and Level 1, the current alert level as we write, is normal life with restriction and quarantine only at the border.

This postscript is being written in week four of Level 1. 
As the initial impact of the pandemic control measures became apparent, there was a marked shift in COVID-19 metaphors. On April 16, as it became apparent that New Zealand had begun to "flatten the curve," Prime Minister Jacinda Ardern used metaphors associated with rugby - New Zealand's national sportto congratulate New Zealanders' efforts, encourage solidarity, and motivate the population to continue their efforts. Setting out the conditions under which New Zealand would move out of lockdown, Ardern stated that "to eliminate COVID-19 will continue to take a team-of-five-million effort" (Cheng 2020). Four days later, as Ardern officially announced the move out of Level 4, she employed the same sporting terminology to congratulate New Zealanders on successfully eliminating community transmission: "the effort of our team of 5 million has broken the chain of transmission and taken a quantum leap forward in our goal to eliminate the virus" (Spinoff 2020).

New Zealand's Director-General of Health, Dr. Ashley Bloomfield-himself an ex-rugby coach-made extensive use of rugby metaphors during each alert level. During Level 3, as New Zealand began to record successive days with no new cases, Bloomfield warned citizens not to become complacent, coaching us that "we're at half time, but we can't take our eye off the ball yet" (NZ Government 2020). On May 5, as New Zealand celebrated its third day with no new cases, Bloomfield's "team talk" continued: "we can't give up before the full-time whistle," he said in his daily news briefing. In an interview on The Breakdown, Bloomfield acknowledged the use of rugby metaphors in directing the collective behavior of New Zealanders was quite deliberate. A crucial part of the "game plan" from early on, Bloomfield told the show, was to treat it like the Rugby World Cup. He recalled:

Right at the start of this . . . one of the analogies I was using with my team is that this is like a Rugby World Cup. Actually, you've got to go out there, you've got to see the team you're playing against in the very first pool matchand you have to have a game plan. You have to play to your plan but you've also got to adapt if things are not going very well. So, in a sense, we've finished the first pool match, and there are others to follow. . . We've got to keep our focus, we've got to keep physically and mentally fit right through the campaign. (Bloomfield 2020)

The reference to sport is not surprising, given its role in the construction of identity. Sporting teams circumscribe the mandatory adversaries into "us and them," "self and other"” (Jutel 2002). In New Zealand, like in many countries of the British Empire, rugby plays a dominant role in the social fabric. By referencing rugby in official communications about COVID-19, New Zealand's leaders tapped into an existing wellspring of national pride and sense of unity - an apparently successful strategy in managing population behavior during lockdown, and beyond. 
Once Ardern and Bloomfield had introduced rugby metaphors into the popular lexicon of COVID-19, the media, opposition MPs, and the wider public adopted these readily. As New Zealand entered Level 3 and citizens were newly allowed to socialize in groups of up to 10 , the police used the "team of five million" phrase to assist their efforts to control gatherings. Explaining action taken for breaches, where the police broke up parties, Acting Assistant Police Commissioner Scott Fraser explained: "Such behaviour could waste all the sacrifices made by our team of five million over the last five weeks" (Clent 2020).

Opposition politicians were also quick to espouse the sporting imagery, with MP Michael Woodhouse using the rugby metaphor against the government in an effort to criticize its contact tracing system. In Parliament on April 30, Woodhouse asked the then Health Minister David Clark: "Does he think that the Government's let the team of five million down by not doing its bit [with contact tracing] soon enough?" Not long afterwards, the terminology was used in Parliament by coalition MP Ron Marks, who drew attention to the poor treatment of supermarket staff during lockdown, stating that "while the team of five million has done a brilliant job, there are just, unfortunately, those elements who have treated our supermarket staff abysmally."

It wouldn't be long before this theme of sport and team spirit would infuse references to COVID-19 in the New Zealand media and on both sides of the political divide. On May 14, the epidemiologist, Roger Morris, writing in the Dominion Post (the metropolitan daily newspaper of New Zealand's capital city and the newspaper with the second-highest distribution in the country) echoed the sports analogy. His review of the COVID-19 situation was titled "Is NZ Winning the World Cup of COVID Control?" and compared New Zealand's "performance" to that of other rugby nations, bragging: "New Zealand has organised and managed its control strategy better. Our alert level system is well-designed, and has provided clear guidance on what was expected, with a high level of community compliance." Morris tied up the article by pointing out the experience of Ebola in Africa, and then reminding readers: "We just need to keep our focus on the goal."

Russell Bell, in the small-town Whanganui Chronicle, mixed his metaphors, starting in rugby and finishing in war: "Much has been made about the team of five million," he started, but rapidly became more cautious. "It seems to me that this could be like celebrating victory in World War II after the Battle of Britain." While the Battle of Britain stopped the German invasion, there were five more years of war to come. The hard slog had only just begun.

Very concerned about the fall out of the pandemic, he detailed the dismal outlook of the economy, and finished: "So, like the call to unite behind a war effort, it is time to unite behind (and support) our tourism and hospitality businesses!" What no one knows of course, is whether control of the coronavirus itself has been achieved, let alone its economic consequences. At the time of writing, we 
are looking with dismay at highest-ever daily cases in Melbourne (Australia), where initially, at least, we thought the war was won.

The rugby metaphor also extended to cultural events and other attempts to kick-start the economy. With the relaxing of restrictions around social distancing measures, the announcement of a tour by the four-piece acoustic band White Chapel Jak was accompanied by proud crowing about the "team": "We're so excited to celebrate what New Zealand, as a team of five million, have achieved during lockdown," exclaimed lead singer and guitarist Bonnie Hurunui (Hawke's Bay Today 2020).

But talking about the team isn't all compliments. The new, and very shortlived leader of the opposition, Todd Muller, grumbled on June 3, "If we're really a team of five million in the fight against Covid-19, then we all need to know what the game plan is." He concluded: "It's time for a Captain's call” (Scoop-Independent News 2020). In this case, the rugby metaphor has been used to condemn national leaders, since it places the actions in the space of human agency and dilutes the natural disaster theme of the early days of the pandemic.

And not surprisingly, COVID-19 itself has become a new metaphor. Radio NZ's report of a huge gang arrest during Level 1 made reference to the arrest of the leaders of a methamphetamine ring in terms of contagion and exclusion from "the team." The report quoted community advocate and lifetime Black Power member Denis O'Reilly: “It's almost as if they've come in with COVID they've come in with an infection and it's not conducive to community or whanaungatanga. It doesn't mean that potentially they're not good people . . . but they're not playing the game, they're not part of the team of five million" (Robson 2020).

From uncontrollable nature to tightly refereed contact sport, the metaphors of COVID-19 reflect the social anxieties and projects of their contexts. At the date of our writing, it has been three months since the last case of community transmission. The vast uncertainties of April have been replaced by a communal sense of relief based on rules, teamwork, and tight social control. The sporting metaphor acts as a comfort blanket for New Zealanders, one that is strengthened by the nation's familiarity with rugby as a means of social identity, as well as a collective investment in success.

\section{REFERENCES}

Aronowitz, R. 2008. "Framing Disease: An Underappreciated Mechanism for the Social Patterning of Health." Soc Sci Med 67 (1): 1-9.

Aubusson, K., D. McCauley, and R. Clun. 2020. "Pandemic Risk Rises: Outbreak Expected amid the Flu Season." Sydney Morning Herald, Feb. 28.

BBC/RNZ. 2020. "China Coronavirus: Lockdown Measures Rise Across Hubei Province.” Radio NZ, Jan. 24. https://www.rnz.co.nz/news/world/408033/china-coronavirus-lockdown-measures-rise-across-hubei-province. 
Bell, R. 2020. "Covid 19 May Be Beaten for Now, but Whanganui Business Needs Our Help.” Whanganui Chronicle, June 10. https://www.nzherald.co.nz/whanganui-chronicle/news/russell-bell-covid-19-may-be-beaten-for-now-but-whanganui-businessneeds-our-help/VSSQFCJOB5TWWHNKAUIACHCXOA/.

Bleakley, A. 2017. Thinking with Metaphors in Medicine: The State of the Art. New York: Routledge.

Bloomfield, A. 2020. Interview. The Breakdown, May 19. Sky Sport, Auckland. Television, $52 \mathrm{~min}$.

Brindley, P. G. 2020. “Life in the Trenches': An Edmonton ICU doctor Describes the War Against COVID-19." National Post, March 31/April 1. https://nationalpost.com/opinion/life-in-the-trenches-an-edmonton-icu-doctor-describes-the-waragainst-covid-19.

Caduff, C. 2019. The Pandemic Perhaps: Dramatic Events in a Public Culture of Danger. Oakland: University of California Press.

Cheng, D. 2020. "Covid 19 Coronavirus: What Alert Level 3 and Other Levels Mean for You." N Z Herald, April 16. https://www.nzherald.co.nz/nz/news/article.cfm?c_ id=1 andobjectid $=12325179$.

Chun, R., and K. Aubusson. 2020. "Health System Braces for 'War."” Sydney Morning Herald, March 6.

Clent, D. 2020. "Coronavirus: No Parties Allowed Under Any Circumstances, Police Warn.” Stuff, May 3. https://www.stuff.co.nz/national/crime/300003342/coronavirus-no-parties-allowed-under-any-circumstances-police-warn.

Clun, R. 2020. "NSW Told to Brace for 1.5m Patients." Sydney Morning Herald, March 26.

Clun, R., and K. Aubusson. 2020a. "Doctor's Infection: Hospital Staff and Patients in Isolation." Sydney Morning Herald, March 25.

Clun, R., and K. Aubusson. 2020b. "Health System Braces for 'War."” Sydney Morning Herald, March 6. https://www.smh.com.au/national/nsw/medical-staff-shortages-expected-for-virus-that-can-t-be-contained-20200305-p54777.html.

Crawford, H., A. Hunter, and D. Filipovic. 2015. All Your Friends Like This: How Social Networks Took Over News. New York: Harper Collins.

Dann, L. 2020a. "Coronavirus and Drought Deliver 'Perfect Storm."” New Zealand Herald, Feb. 26. https://www.nzherald.co.nz/business/news/article.cfm?c_id=3andobjectid $=12311605$.

Dann, L. 2020b. "Spread of Virus Makes Markets Jittery." New Zealand Herald, Feb. 25.

Derrida, J. 1967. Of Grammatology. Trans. G. C. Spivak. Baltimore: Johns Hopkins University Press, 1988.

Derrida, J. 1974. "White Mythology: Metaphor in the Text of Philosophy." Trans. F. C. T. Moore. New Literary Hist 6 (1): 5-74. DOI: 10.2307/468341.

Derrida, J. 1982. Margins of Philosophy. Brighton: Harvester Press.

Dunlevey, S. 2020. "What Australia's Frontline Workers Need to Wage War on Virus." Chronicle, April 1. https://www.thechronicle.com.au/news/what-australias-frontlineworkers-need-to-wage-war/3986161/.

Dyer, G. 2020. "China’s Sluggish Response to Killer Virus Allows It to Spread Worldwide". N Z Herald, Jan. 28. https://www.nzherald.co.nz/health/news/article.cfm?c_ $\mathrm{id}=204$ andobjectid $=12303688$. 
European Centre for Disease Prevention and Control (ECDC). (2020). "Case Definition and European Surveillance for COVID-19, as of 2 March 2020." Solna, Sweden: European Union.

Gray, N. J., et al. 2005. "Health Information-Seeking Behaviour in Adolescence: The Place of the Internet." Soc Sci Med 60 (7): 1467-78.

Hanne, M., and S. J. Hawken. 2007. "Metaphors for Illness in Contemporary Media." Med Humanit 33 (2): 93-99. DOI: 10.1136/jmh.2006.000253.

Hannon, D. 2020. "This Unprecedented Curtailment of Our Freedom Must End as Soon as Possible." Daily Telegraph, March 28. https://www.telegraph.co.uk/ news/2020/03/28/unprecedented-curtailment-freedom-must-end-soon-possible/.

Harris, C. 2020. "Mitre 10, Briscoes Join Smiths City and The Warehouse in Selling Essentials During Lockdown.” Stuff, March 31. https://www.stuff.co.nz/business/120695471/the-warehouse-opens-for-limited-business-during-lockdown?utm source $=$ dlvr.it\&utm_medium $=$ twitter.

Hawke's Bay Today. 2020. “We're Back!” Hawke’s Bay Today, June 20.

Ireland, J. 2020. "Virus Sparks Racism Fear." Sydney Morning Herald, Feb. 15.

Jutel, A. 2002. "Olympic Road Cycling and National Identity: Where Is Germany?" J Sport Soc Issues 26 (2): 195-208.

Jutel, A. 2011. Putting a Name to It: Diagnosis in Contemporary Society. Baltimore: Johns Hopkins University Press.

Jutel, A. 2013. "When Pigs Could Fly: Influenza and the Elusive Nature of Diagnosis." Perspect Biol Med 56 (4): 513-29. DOI: 10.1353/pbm.2013.0033.

Jutel, A. 2020. "Coronavirus Calls for Sensible Language.” Newsroom, Feb. 19. https:// www.newsroom.co.nz/ideasroom/2020/02/19/1041870/coronavirus-calls-for-sensible-language.

Kahneman, D. 2011. Thinking, Fast and Slow. New York: Farrar, Straus and Giroux.

Kelly, P. M. 2020. "Coronavirus: Australia Unites for War on Home Soil.” Australian, April 1. https://www.theaustralian.com.au/commentary/coronavirus-australiaunites-for-war-on-home-soil/news-story/a4535cb961e49803328b2fc5d4ac8ff2.

Krugman, P. 2020. "Covid-19 Brings Out All the Usual Zombies." NY Times, March 28. https://www.nytimes.com/2020/03/28/opinion/coronavirus-trump-response.html.

Lutz, E. 2020. "New York Coronavirus Deaths Are Reaching 'Apocalyptic' Heights." Vanity Fair, March 26. https://www.vanityfair.com/news/2020/03/new-york-coronavirus-deaths-are-reaching-apocalyptic-heights.

Mannix, L., R. Clun, and K. Aubusson. 2020. "Threat of Pandemic Intensifies." Sydney Morning Herald, Feb. 25.

Marks, R. 2020. Parliamentary Debates: General Debate. House of Representatives. Wellington: Hansard.

Ministry of Health. 2020a. Case Definition of COVID-19 Infection, March 8. Wellington: New Zealand Government.

Ministry of Health. 2020b. COVID-19 Case Definitions, April 1. Wellington: New Zealand Government.

New Zealand (NZ) Government. 2020. COVID-19 Updates. Beehive.govt.nz.

New Zealand Herald. 2020. "COVID 19 Coronavirus: US Cases Surge, WHO Says Pandemic Threatens Whole of Humanity." N Z Herald, March 26. 
Novitz, D. 1985. “Metaphor, Derrida, and Davidson.” J Aesthetics Art Crit 44 (2): 101-14. Okri, B. 2020. "Fear of COVID-19 Is a Mental Contagion-and That's Something We Can Fight." Guardian, March 26. https://www.theguardian.com/commentisfree/2020/mar/26/fear-of-covid-19-is-a-mental-contagion-ben-okri.

Pelling, R. 2020. "Even the Blitz Couldn't Close Our Pubs: This Lockdown Is a Bitter Blow." Telegraph, March 12. https://www.telegraph.co.uk/news/2020/03/17/evenblitz-couldnt-close-pubs-bitter-blow/.

Peters, W., Rt Hon. 2020. "New Zealanders Overseas Encouraged to Shelter in Place." Press release. New Zealand Government. https://www.beehive.govt.nz/release/ new-zealanders-overseas-encouraged-shelter-place.

Potts, A., and E. Semino. 2019. "Cancer as a Metaphor." Metaphor Symbol 34 (2): 81-95.

Powell, R. 2020. “'Who Knows?': Gerry Harvey Wary of Coronavirus as Store Profits Drop." Sydney Morning Herald, Feb. 28. https://www.smh.com.au/business/companies/harvey-norman-profit-slips-as-coronavirus-clouds-outlook-20200227-p5450f. html.

Raffel, S. 2013. The Method of Metaphor. Chicago: Intellect Books.

Robson, S. 2020. "Gang Arrests: 'They're Not Part of the Team of Five Million."” Radio N Z Newswire, June 24.

Schutz, A. 1967. The Phenomenology of the Social World. Evanston: Northwestern University Press.

Schutz, A. 1970. On Phenomenology and Social Relations: Selected Writings. Chicago: University of Chicago Press.

Scoop-Independent News. 2020. "It's Time for A Captain's Call on Level 1." Scoop-Independent News, June 3. https://www.scoop.co.nz/stories/PA2006/S00031/its-time-for-acaptains-call-on-level-1.htm.

Semino, E., and Z. Demjén. 2016. Routledge Handbook of Metaphor and Language. New York: Routledge.

Shove, E., M. Pantzar, and M. Watson. 2012. The Dynamics of Social Practice: Everyday Life and How It Changes. Los Angeles: SAGE.

Soncul, Y. 2018. "The Mask of Ebola: Fear, Contagion, and Immunity." In Affect and Social Media: Emotion, Mediation, Anxiety and Contagion, ed. T. Sampson, S. Maddison, and D. Ellis, 157-67. Lanham, MD: Rowman and Littlefield.

Sontag, S. 1978. Illness as Metaphor. New York: Farrar, Straus and Giroux.

Spinoff. 2020. "Let's Finish What We Started: Jacinda Ardern Announces Move to Level 3." Spinoff, April 20. https://thespinoff.co.nz/politics/20-04-2020/lets-finish-whatwe-started-jacinda-ardern-announces-move-to-level-three/.

Tang, X., et al. 2020. "On the Origin and Continuing Evolution of SARS-CoV-2." National Sci Rev. DOI: 10.1093/nsr/nwaa036.

Tisdall, S. 2020. "Lay Off Those War Metaphors, World Leaders: You Could Be the Next Casualty." Guardian, March 21.

Todd, K. 2020. "Health Ministry Alerts Hospitals to New Deadly Virus in China." Radio N Z, Jan. 15. https://www.rnz.co.nz/news/national/407390/health-ministry-alertshospitals-to-new-deadly-virus-in-china.

Vaterlaus, J. M., et al. 2015. "Getting Healthy: The Perceived Influence of Social Media on Young Adult Health Behaviors." Comput Hum Behav 45: 151-57. 
Walls, J. 2020. "Weather the Storm: PM Jacinda Ardern Announces New COVID-19 Coronavirus Quarantine Powers for Officials.” N Z Herald, March 9. https://www. nzherald.co.nz/nz/news/article.cfm?c_id=1 andobjectid=12315223.

Weiner, G. 2020. “Are We Sure We Want to Give Trump War Powers?” NY Times, March 25. https://www.nytimes.com/2020/03/25/opinion/trump-executive-authority-covid.html.

Wheeler, S. C., III. 2016. "Metaphor Without Meanings: Derrida and Davidson as Complementary." In Beyond the Analytic-Continental Divide: Pluralist Philosophy in the Twenty-First Century. ed. J. A. Bell, A. Cutrofello, and P. M. Livingston, 172-90. New York: Routledge.

Woodhouse, M. 2020. Parliamentary Debates: Question Time. House of Representatives. Wellington: Hansard. 